\title{
Sentetik ve Modern Ekmeklik Buğday Genotiplerinin (Triticum aestivum L.) Verim ve Kalite Özelliklerinin Karşılaştırılması
}

\author{
Hüsnü Aktaşs ${ }^{1 *}$ Mehmet Karaman $^{2} \quad$ İrfan Erdemci ${ }^{2} \quad$ Enver Kendal $^{1} \quad$ Sertaç Tekdal ${ }^{2}$ \\ Hasan Kılıç3 Erol Oral $^{1}$ \\ ${ }^{1}$ Mardin Artuklu Üniversitesi Kızıltepe MYO, Bitkisel ve Hayvansal Üretim Bölümü, Mardin \\ ${ }^{2}$ GAP Uluslararası Tarımsal Araştırma ve Eğitim Merkezi, Diyarbakır \\ ${ }^{3}$ Bingöl Üniversitesi Ziraat Fakültesi, Tarla Bitkileri Bölümü, Bingöl
}

Kabul tarihi (Accepted): 22.05.2017

\begin{abstract}
Anahtar kelimeler:
Özet. Bu çalışma, kışlık gelişme tabiatına sahip 14 modern ekmeklik ve 11 sentetik buğday Sentetik buğday, verim, kalite genotipinin tane verimi ve bazı kalite özellikleri bakımından karşılaştırılması amacıyla 201415 ve 2015-16 yetiştirme sezonlarında Elazığ ili sulu şartlarında yürütülmüştür. Denemeler tesadüf blokları deneme deseninde 3 tekerrürlü olarak kurulmuş, birleştirilmiş varyans analiz sonuçlarına göre incelenen tüm özellikler bakımından genotipler arasındaki fark 0.01 düzeyinde istatistiki olarak önemli bulunmuştur. İki yıllık ortalama sonuçlara göre, sentetik ve modern ekmeklik buğday genotiplerinin tane verimi ortalaması sırasıyla 720 ve $707 \mathrm{~kg}$ $\mathrm{da}^{-1}$; bin tane ağırlığı için 41.42 ve 37.35 g; protein oranı için \%10.71 ve \%10.79; yaş gluten değeri \%31.7 ve \%30.7 olarak tespit edilmiştir. Çalışmada sentetik buğday genotipleri bin tane ağırlığı bakımından daha üstün özelliğe sahipken, tane verimi bakımından daha yüksek bir ortalamaya sahip olmalarına rağmen bariz bir üstünlük tespit edilememiştir. ANOVA ve GGE biplot analizleri sonucuna göre sentetik buğday genotipi S-4'ün bin tane, yaş gluten ve protein özellikleri bakımından, modern ekmeklik buğday genotipi M-3'ün ise zeleny

*Sorumlu yazar

h_aktas47@hotmail.com sedimantasyon ve hektolitre özellikleri için en ideal değerlere sahip olduğu tespit edilmiştir. Çalışma sonucunda sentetik buğday genotiplerinin tane verimi ve kalite özellikleri bakımından iyi bir potansiyele sahip olmakla beraber, dikkatli ve etkili bir seleksiyon ile modern ekmeklik buğday genotiplerinden daha üstün özelliklere sahip sentetik buğday genotiplerin belirlenebileceği ve bu konuda daha kapsamlı çalışmaların yapılması gerektiği sonucuna varılmıştır.
\end{abstract}

\section{Comparasion Grain Yield and Quality Traits of Synthetic and Modern Wheat Genotypes (Triticum aestivum L.)}

\section{Keywords:}

Synthetic wheat, yield, quality

\begin{abstract}
This study was conducted in 2014-15 and 2015-16 seasons under irrigation condition of Elazığ province to compare 14 modern hexaploid and 11 sythetic wheat genotypes regarding to grain yield and some quality traits. Experiment was performed in randomized complete-block design with three replications. According to combined variance analysis statistically significant differences $(\mathrm{P}<0.05$ or $\mathrm{P}<0.01)$ were determined for all examined traits of genotypes. According to mean of two years; examined traits of synthetic and modern hexaploid wheat were 720 and $707 \mathrm{~kg} \mathrm{da}^{-1}$ for grain yield; 41.42 and 37.35 for thousand kernel weight; 10.71 and $10.70 \%$ for protein content; 31.7 and $30.7 \%$ for wet gluten respectively. Results indicated that synthetic wheat genotypes had desirable value for thousand kernel weight compare to modern hexaploid wheat genotypes. Although mean grain yield of synthetic wheat was higher but difference between two groups was very small. ANOVA and GGE biplot analysis also indicated that synthetic wheat genotype S-4 was superior for thousand kernel weight, wet gluten and protein content, while modern bread wheat genotype $M-3$ showed higher value for zeleny sedimentation and test weight. Study concluded that synthetic wheat had potential for grain yield and quality traits careful and efficient selection need to determine superior synthetic wheat genotypes. Also, further study should be conducted related to synthetic wheats.
\end{abstract}


Aktaş ve ark., Sentetik ve Modern Ekmeklik Buğday Genotiplerinin (Triticum aestivum L.) Verim ve Kalite Özelliklerinin Karşılaştırılması

\section{GiRiş}

Yüksek verimli ve besinsel değeri daha yüksek olan buğday çeşitlerinin geliştirilmesi amacıyla yapılan yoğun ıslah çalışmaları sonucunda, kültür formlarının genetik çeşitliliği giderek azalmış, zararlılara, çevresel streslere ve değişik hastalıklara karşı hassasiyetleri de artmıştır (Baloch et al., 2014; Baloch et al., 2017). Bu nedenle kalite parametreleri, biyotik ve abiyotik stres koşulları için genetik variabiliteyi artıracak gen allellerine intiyaç duyulmaktadır (Hajjar and Hodgkin 2007). Tr. dicoccum ve Ae. squraossa türleri verim, hastalık, stres koşullarına dayanıklılık ve kaliteye etki eden genler taşıması nedeniyle ıslah programlarında kullanılmaktadır (Luo et al., 1998). Bu türler aynı zamanda verim potansiyelinin artırılması için de kullanılmaktadır. Kültür buğdaylarının gen havuzlarının zenginleştirilmesi ve iyileştirilmesinde buğdayın yabani akrabalarından Aeg. squarrossa $(2 n=14 D D)$ ile $T$. dicoccum $(2 n=28, A A B B)$ veya $T$. durum $(2 n=28$, $A A B B$ ) türleri arasında melezlemeler yapıldıktan sonra embriyo kurtarma tekniği kullanılarak primer sentetik hekzaploid ekmeklik buğdaylar $(2 n=42, A A B B D D)$ elde edilmektedir. Elde edilen bu genotipler modern hekzaploid buğdaylarla 2 defa geri melezleme yolu ile agronomik olarak uygun (kolay harman olan ve uygun bitki boylu gibi) genotipler elde edilebilmekte ve bu yolla elde edilen genotipler "Sentetik Hekzaploid Buğdaylarla Geliştirlimiş Genotipler" olarak tanımlanmaktadır (Mujeeb-Kazi et al., 1996).

Bugüne kadar CIMMYT orjinli sentetik hatlar kullanılarak "mega environment" olarak adlandırılan çoklu lokasyonlardaki deneme sonuçlarına göre modern hekzaploid ekmeklik buğdaylardan daha üstün, kaliteli ve verimli genotipler elde edildiği, CIMMYT'in yarı kurak alanlar deneme setlerine (SAWYT) ait materyalin yaklaşık \%30'unun sentetik buğdaylarla melezlenmiş olan hatlardan ibaret olduğu, ayrıca İspanya ve Çin'de toplam 6 adet CIMMYT materyali sentetik orjinli buğday hattının tescil edildiği ve bu çeşitlerin üstün özelliklerinden dolayı çok geniş alanda ekildiği ve bu çeşitlerden 'Chuanmai 42 ' isimli çeşidin 100.000 ha ekim alanına sahip olduğu, aynı zamanda melezleme programlarında en fazla kullanılan ebeveynlerden birisi olduğu bildirilmiştir (Lage and Trehotwan 2008). Son 20 yılda yabani buğdaylar kullanılarak yeni çeşitler geliştirme amaçlı çalışmalarda çok sayıda özelliğin yabani buğday türlerinden aktarıldığı, yabani buğdaylardaki genlerin homolog kromozom rekombinasyonuyla kültür buğdaylarına aktarılabileceği ve ekmeklik buğdaylardaki 3 genomun homolog kromozomlara sahip olması veya benzer genetik yapıya sahip olmasının bu anlamda çok önemli bir avantaj olduğu da birçok araştırmacı tarafından bildirmiştir (Cox and Sears 1995; Hajjar and Hodgkin 2007). ICARDA' da 1994 yılında başlatılmış olan ön ıslah (pre-breeding) programı kapsamında yabani buğdaylardan yararlanılarak çalışmalar yapılmakta ve bu çalışmalar sonucunda birçok özellik bakımından yeni gen allelleri bulunduğuna ve bu anlamda genetik varyasyonu artırmak için yabani buğdaylardan yararlanılabileceğine dair birçok sonuç bulunmaktadır (Valkoun 2001).

Yapılan bu çalışmada, sentetik ekmeklik buğday genotiplerinin, ekmeklik buğday genotipleri ile bazı özellikler bakımından karşılaştııılması ve yüksek verimli aynı zamanda kalite parametreleri açısından sentetik buğdayların potansiyel kapasitelerinin araştııılması amacıyla, 14 adet kışlık ekmeklik buğday genotipi ile 11 adet sentetik kışlık ekmeklik buğday genotipi material olarak kullanıımış, çalışma Elazığ'da 2014-15 ve 2015-16 sezonlarında sulu koşullarda yürütülmüştür.

\section{MATERYAL VE METOD}

\section{Materyal}

Çalışmada, 14 modern kışlık ekmeklik buğday genotipi ile Teksas Üniversitesinden temin edilmiş olan kışlık gelişme tabiatına sahip 11 adet sentetik buğday genotipi kullanılmıştır (Çizelge 1).

\section{Metod}

Ekim işlemi metrekarede 450 adet tohum olacak şekilde, en uygun ekim zamanında (15 Kasım ile 30 Kasım arası) deneme mibzeri ile $5 \mathrm{~m}$ uzunluk $\times 1.2 \mathrm{~m}$ genişlikte toplam $6 \mathrm{~m}^{2 \prime}$ lik alana ekim yapılmıştır. Denemeler her iki yılda da tesadüf blokları deneme desenine göre 4 tekerrürlü olarak kurulmuştur. Saf madde üzerinden hesapla, ekimle birlikte $8 \mathrm{~kg} \mathrm{da}^{-1}$ $\left(\mathrm{P}_{2} \mathrm{O}_{5}\right)$ ve $8 \mathrm{~kg} \mathrm{da}^{-1}$ azot $(\mathrm{N})$, kardeşlenme döneminde ise $8 \mathrm{~kg} \mathrm{da}^{-1}$ azot olacak şekilde gübre uygulanmıştır. Kardeşlenme döneminin sonunda ve bütün genotipler başaklandıktan sonra toplamda iki defa sulama yapılmıştır.

Tane verimi, bin tane ağırlığı, hektolitre ağırlığı değerleri Pask (2012)'in belirttiği yöntemler kullanılarak elde edilmiştir. Tane verimi $6 \mathrm{~m}^{2 \prime}$ lik parsellerin hasadı sonunda laboratuvara getirilen tohum örnekleri hassas terazide tartılarak elde edilen tane verimi ağırlığı dekara çevrilmiştir. 1000 tane ağılığı, hasadı yapılan deneme parsellerinden elde edilen tohumların hassas tartıda 
Aktaş ve ark., Sentetik ve Modern Ekmeklik Buğday Genotiplerinin (Triticum aestivum L.) Verim ve Kalite Özelliklerinin Karşılaştırılması

Çizelge 1. Çalışmada kullanılan sentetik ve modern buğday genotipleri.

Table 1. Synthetic and modern wheat genotypes used in study.

\begin{tabular}{|c|c|c|}
\hline & Genotip Kodu & Çeşit/Pedigri \\
\hline \multirow{14}{*}{ 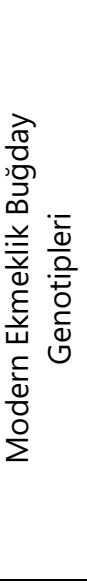 } & M-1 & PRESL/4/VPM/MOS 83-11-4-8//PEW/3/AFG2/BUC,F1//KVZ \\
\hline & M-2 & PEHL//RPB 8-68/CHRC/3/506/88-113 \\
\hline & $M-3$ & CAR422/ANA//YACO/3/KAUZ*2/TRAP//KAUZ/4/BUCUR/5/BUCUR \\
\hline & $M-4$ & KRASUNIA \\
\hline & $M-5$ & ID\#840335//Pın39/Pew/3/Dmnt \\
\hline & M-6 & PEHLIVAN \\
\hline & M-7 & SYRENA \\
\hline & M-8 & TAM200/KAUZ//BECUNA-6 \\
\hline & M-9 & BLUEGIL-2/BUCUR//SIRENA \\
\hline & $M-10$ & GUN91/MNCH*2//T-2003 \\
\hline & $M-11$ & ID800994.W/VEE//BAU/KAUZ/3/PYN/BAU \\
\hline & $M-12$ & CEMRE \\
\hline & $M-13$ & KS940786-6-7/BONITO-36//TASICAR \\
\hline & $M-14$ & KLEIBER/2*FL80//DONSK.POLUK./3/KS82W409/STEPHENS/4/HATUSHA \\
\hline \multirow{11}{*}{ 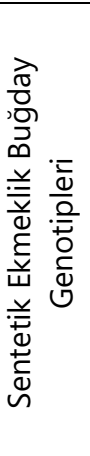 } & S-1 & TAM 112*2/CIMMYT E95SYN4152-37 \\
\hline & $\mathrm{S}-2$ & TAM 111*2/CIMMYT E2SYN4153-31 \\
\hline & $\mathrm{S}-3$ & TAM 111*2/CIMMYT E95SYN4152-61 \\
\hline & S-4 & TAM 112*2/CIMMYT E95SYN4152-16 \\
\hline & S-5 & TAM 111*2/CIMMYT E95SYN4152-61 \\
\hline & S-6 & TAM 112*2/CIMMYT E95SYN4152-5 \\
\hline & S-7 & TAM 111*2/CIMMYT E95SYN4152-78 \\
\hline & $\mathrm{S}-8$ & TAM 111*2/CIMMYT E95SYN4152-51 \\
\hline & S-9 & TAM 112*2/CIMMYT E95SYN4152-5 \\
\hline & S-10 & TAM 112*2/CIMMYT E95SYN4152-5 \\
\hline & S-11 & TAM 112*2/CIMMYT E95SYN4152-78 \\
\hline
\end{tabular}

tartılmasıyla g $1000^{-1}$ tane olarak; hektolitre ağırlığı 1 It'lik ölçek ile tartılarak bulunan değerin 100 ile çarpılmasıyla elde edilmiştir. Protein oranı NIR (Near Infrared model 6500) cihazı kullanılarak AACC 39-10 metoduna göre (Anonim 1990) \% olarak; Zeleny sedimantasyon değeri ICC-No. 115'e (Anonim 1982) göre; yaş gluten oranı gluten yıkama cihazında ICCstandart no: 155 (Anonim 1994) metoduna göre tayin edilmiştir. 2014-15 sezonunda toplam yağış $411 \mathrm{~mm}$ ve 2015-16 sezonunda ise $462 \mathrm{~mm}$ olarak kaydedilmiştir.

\section{BULGULAR VE TARTIŞMA}

\section{Varyans Analiz Sonuçları}

Sentetik ve modern ekmeklik buğday genotiplerinin materyal olarak kullanıldığı ve sulu şartlarda yürütülen iki yıllık çalışmada elde edilen veriler birleştirilmiş varyans analize tabi tutulmuştur. Birleştirilmiş varyans analiz sonuçlarına göre, incelenen tüm özellikler bakımından genotipler arasındaki fark 0.01 düzeyinde istatistiki olarak önemli bulunmuştur (Çizelge 2). Tane verimi, bin tane ağırlığı, protein oranı ve zeleny sedimantasyon değerleri bakımından yılların ortalaması arasındaki fark 0.01 veya 0.05 düzeyinde istatistiki olarak önemli bulunurken, diğer özellikler için yıllara arasındaki fark önemsiz olarak bulunmuştur. Genotip*Yll interaksiyonu ( $G^{*} Y$ interaksiyonu) bakımından bin tane ağırlığı, hektolitre ağırlığı, gluten oranı ve zeleny sedimantasyon değerleri için istatistiki olarak önemli, diğer özellikler için ise önemsiz olarak tespit edilmiştir (Çizelge 2). Elde edilen bu sonuçlar, çalışmanın sulu şartlarda yürütülmesine rağmen, yıllar arasındaki toplam yağış ve sıcaklık gibi faktörlerin bazı özellikler için farklılıkların oluşmasına neden olduğunu göstermektedir. Nitekim, birçok çalışmada buğday genotiplerinin farklı çevre veya yıllardaki tane verimi ve kalite değerlerinin etkilendiğini bildirilmiştir (Kılıç et al., 2010).

\section{Tane Verimi}

Çalışmada kullanılan sentetik ve modern ekmeklik buğday genotplerinin tane verimi ortalamaları Çizelge 3'te verilmiştir. Buna göre, tüm genotiplerin ortalama tane verimi değeri $713 \mathrm{~kg} \mathrm{da-1}$, modern buğday genotiplerinin ortalama verimi $707 \mathrm{~kg} \mathrm{da}^{-1}$ ve sentetik buğday genotiplerinin ortalama verimi ise $720 \mathrm{~kg} \mathrm{da}^{-1}$ olarak tespit edilmiştir. Buna göre sentetik buğday genotiplerinin tane verimi bakımından ortalaması daha yüksek olmasına rağmen, bariz bir üstünlük söz konusu değildir. Diğer taraftan, en yüksek tane verimi ortalaması modern ekmeklik buğday grubundan M- 
Aktaş ve ark., Sentetik ve Modern Ekmeklik Buğday Genotiplerinin (Triticum aestivum L.) Verim ve Kalite Özelliklerinin Karşılaştırılması

Çizelge 2. Varyans analiz tablosu.

Table 2. Table of variance analysis.

\begin{tabular}{|c|c|c|c|c|c|c|c|}
\hline \multirow[b]{2}{*}{ Kaynaklar } & \multirow[b]{2}{*}{ Sd } & \multirow[b]{2}{*}{ TV } & \multicolumn{4}{|c|}{ Kareler Ortalaması } & \multirow[b]{2}{*}{ ZS } \\
\hline & & & BTA & HL & PRT & GLT & \\
\hline Yıl & 1 & $107951^{\star *}$ & $1515^{\star *}$ & 4.02 öd & $29 *$ & $122^{*}$ & $242 *$ \\
\hline Tek [Yıl] \& Random & 4 & 767 öd & 7.22 öd & 4.58 öd & 2.14 öd & 7.2 öd & 20.23 öd \\
\hline Genotip & 24 & $107951^{\text {** }}$ & $103^{\star *}$ & $27.84^{* *}$ & $3.94^{* *}$ & $74^{\star *}$ & $554^{\star \star}$ \\
\hline YIl x Çesit & 24 & 1662 öd & $14.53^{* *}$ & $3.55^{\star}$ & 0.99 öd & $6.81^{* *}$ & $15.1^{*}$ \\
\hline CV (\%) & & 8.91 & 5.1 & 1.9 & 5.6 & 6.4 & 7.1 \\
\hline
\end{tabular}

TV: Tane verimi; BTA: Bin tane ağırlığı; HL: Hektolitre ağırlığı; PRT: Protein oranı; GLT: Gluten oranı; ZS: Zeleny sedimantasyon değeri; Sd: Serbestlik derecesi; * 0.05 düzeyinde, ${ }^{* *} 0.01$ düzeyinde önemli

$12\left(783 \mathrm{~kg} \mathrm{da}^{-1}\right)$ ve M13 (771 kg da-1) genotiplerinden elde edilirken, yüksek tane verimine sahip olan S-15 $\left(771 \mathrm{~kg} \mathrm{da}^{-1}\right)$, S-21 $\left(750 \mathrm{~kg} \mathrm{da}^{-1}\right)$ ve S-22 $\left(753 \mathrm{~kg} \mathrm{da}^{-1}\right)$ sentetik buğday genotipleri, en yüksek tane verimine sahip modern ekmeklik buğday genotipleri ile aynı istatistiki grupta yer almışlardır. Bu sonuçlar modern ve sentetik genotiplerinin tane verimi bakımından yakın benzer değerlere sahip olduğunu göstermektedir. Tane verimi bakımından ortalama değerlerin birbirine yakın olması çalışmanın sulu koşullarda yürütülmüş olmasından dolayı kaynaklandığı öngörülmektedir. Primer sentetik buğdaylarla melezlenerek elde edilmiş olan buğday hatları ile bu hatların ebeveynlerinin tane verimi bakımından karşılaştırıldığı çalışmalarda, bu hatların ebeveynlerinden ve standart olarak kullanılan çeşitlerden \%8 ile \%30 arasında daha fazla verim performansı gösterdiklerini ve dikkatli, etkili bir seleksiyon ile modern ekmeklik buğdaylardan üstün özelliklere sahip sentetik genotiplerin belirlenebileceği bildirilmiştir (Ogbonnaya et al., 2006; Dreccer et al., 2007).

\section{Bin Tane Ağırlığı}

Bin tane ağırlığı, genotipik bir karakter olsa da çevresel faktörlerden etkilenmektedir (Rahman et al., 2009). Tüm genotiplerin ortalama bin tane ağırlığı $39.14 \mathrm{~g}$ olarak kaydedilirken, modern ekmeklik buğday genotiplerinin ortalama bin tane ağırlığı değeri 37.35 $\mathrm{g}$, sentetik buğday genotiplerine ait ortalama bin tane ağırlığı ise $41.42 \mathrm{~g}$ olarak kaydedilmiştir, Modern ekmeklik buğday genotipleri içerisinde en yüksek değer M-1 (44.57 g) ve M-12 (40.50 g)'den, sentetik buğday genotipleri içerisinde ise S-18 $(47.33 \mathrm{~g}), \mathrm{S}-19$ $(45.80 \mathrm{~g}), \mathrm{S}-21(44.41 \mathrm{~g})$ ve S-15 $(43.53 \mathrm{~g}){ }^{\prime}$ den elde edilmiştir. Bu sonuçlar, sentetik buğday genotiplerinin bin tane ağırlığı bakımından bariz bir üstünlüğü olduğunu göstermektedir. Birçok araştırmacı sentetik buğdayın daha uzun ve daha geniş buğday tanesine sahip buğday genotiplerinin geliştirilmesi için tanenin hem fiziksel hem de kimyasal tekstüründe geniş bir varyasyona sahip olduğunu bildirmiştir (Yueming et al., 2003; Gedye et al., 2004).

\section{Hektolitre Ağırlığı}

Hektolitre ağırlığı, tanedeki karın boşluğu, tanenin buruşukluğu gibi tane yapısının genel özelliklerinden etkilenmekle beraber yetiştirme sezonu içerisindeki yağış ve sıcaklık gibi faktörler de hektolitre ağırlığına etki etmektedir (Aguirre et al., 2002). Bütün genotiplerin ortalama hektolitre değeri $81.36 \mathrm{~kg} \mathrm{hl}^{-1}$, modern ekmeklik buğday genotiplerinin ortalaması $81.30 \mathrm{~kg} \mathrm{hl}^{-1}$ ve sentetik ekmeklik buğday genotiplerinin ortalamsı ise $81.40 \mathrm{~kg} \mathrm{hl}^{-1}$ olarak tespit edilmiştir. Modern ekmeklik buğday genotipleri içerisinde en yüksek değere $M-7\left(85.1 \mathrm{~kg} \mathrm{~h}^{-1}\right)$ ve $\mathrm{M}-5$ $\left(84.3 \mathrm{~kg} \mathrm{hl}^{-1}\right)$ genotipleri, sentetik buğday genotipleri içerisinde de S-20 (83.6 kg hl$\left.{ }^{-1}\right)$ sahip olmuştur. Hektolitre ağırlığı bakımından her iki genotip grubu birbirine yakın hektolitre ağırlığı değerlerine sahip olduğu tespit edilmiştir.

\section{Protein Oranı}

Buğday kalitesini belirlemede en yaygın kullanılan parametre olan protein miktarı, çevresel ve genetik faktörlere bağlı olarak değişmekte olduğu ve özellikle çevresel faktörlerden toprak verimliliği, yetiştirme sezonu içerisindeki yağış miktarı, dağılımı, sıcaklık ve hastalıkların protein oranı üzerinde etkisinin önemli olduğu belirtilmektedir (Cornish et al., 2006). Protein oranı ortalaması bakımıdan modern ve sentetik buğday genotipleri benzer değerlere sahip olurken, en yüksek protein değerleri sırasıyla S-4 (\%12.55), M-1 (\%12.3), M-3 (\%12.3) ve S-14 (\%11.72) genotiplerinden elde edilmiştir. Sentetik ve modern ekmeklik buğday genotiplerinin birbirlerine bariz bir üstünlüğü tespit edilememiştir. Lage et al. (2006) modern ekmeklik buğday ıslah hatları ile sentetik buğday genotiplerinin kalite özelliklerini karşılaştırdıkları çalışmada, sentetik hekzaploid buğday genotiplerinin ortalama protein oranının \% 15.5, kontrol çeşit "Seri M82"de ise \% 13.1 olarak tespit edildiğini ve sentetik buğdayların 
Aktaş ve ark., Sentetik ve Modern Ekmeklik Buğday Genotiplerinin (Triticum aestivum L.) Verim ve Kalite Özelliklerinin Karşılaştırılması

istatistiki olarak önemli daha yüksek protein oranına sahip olduğunu bildirmiştir.

\section{Yaş Gluten Oranı}

Buğday genotiplerindeki yaş gluten miktarı, protein oranı gibi gübreleme, yıl içerisindeki yağış miktarı ve zamanı, sulama ve diğer yetiştirme tekniklerinden etkilenmekte, genel olarak sulu koşullardaki yaş gluten oranı düşük olmaktadır (Şahin ve ark., 2004). Yapılan bu çalışmada, genotiplerin genel ortalama yaş gluten oranı değeri \%31.1, modern ekmeklik buğday genotiplerinin $\% 30.7$ ve sentetik buğday genotiplerinde ise \%31.7 olarak gerçekleşmiştir. Bu çalışma sulu koşullarda yürütüldüğü için genotiplerin hem protein hem de yaş gluten özelliklerinde varyasyonun düşük olduğu öngörülmüştür. Lage et al. (2006) sentetik buğday genotiplerinin, modern ıslah çeşitlerine bariz bir üstünlüğünün tespit edilmediğini, fakat bazı sentetik hatlar içerisinde kontrol olarak kullandıkları "Seri M82" çeşidinden daha yüksek yaş gluten oranına sahip genotipler tespit ettiklerini bildirmiştir.

Çizelge 3. İncelenen karakterlerin iki yıllık ortalama değerleri ve oluşan gruplar.

Table 3. Mean of two years data for examined traits and statistical groups.

\begin{tabular}{|c|c|c|c|c|c|c|}
\hline Genotipler & TV & BTA & HL & PRT & GLT & ZSDS \\
\hline$M-1$ & $638 \mathrm{Ik}$ & $44.78 \mathrm{~b}$ & 82.7be & $12.3 a$ & $35.2 \mathrm{c}$ & $35.70 \mathrm{j}$ \\
\hline$M-2$ & 714 cf & $32.36 \mathrm{j}$ & $81.1 \mathrm{eg}$ & 10.72be & $29.6 \mathrm{fl}$ & $43.20 \mathrm{fg}$ \\
\hline$M-3$ & $612 k$ & زا 34.08 & $83.1 \mathrm{bd}$ & $12.3 a$ & $35.4 \mathrm{c}$ & $56.20 a b$ \\
\hline$M-4$ & $707 \mathrm{dg}$ & $29.65 \mathrm{k}$ & $80.8 \mathrm{gh}$ & $10.00 \mathrm{df}$ & $24.4 \mathrm{k}$ & $27.45 \mathrm{k}$ \\
\hline$M-5$ & $699 \mathrm{eg}$ & $39.38 \mathrm{eg}$ & $84.3 \mathrm{ab}$ & $10.07 \mathrm{df}$ & $30.2 \mathrm{fh}$ & $39.70 \mathrm{hl}$ \\
\hline$M-6$ & $667 \mathrm{gl}$ & $38.65 \mathrm{fg}$ & 78.61 & $10.47 \mathrm{cf}$ & $29.2 \mathrm{gl}$ & $43.70 \mathrm{eg}$ \\
\hline$M-7$ & 718 cf & 34.85 I & $85.1 \mathrm{a}$ & 10.8 be & 29.1 hj & $54.45 \mathrm{~b}$ \\
\hline$M-8$ & $707 \mathrm{df}$ & $35.96 \mathrm{hl}$ & $83.1 \mathrm{bd}$ & $10.07 \mathrm{df}$ & $29.6 \mathrm{fl}$ & $48.95 \mathrm{~cd}$ \\
\hline$M-9$ & 723 cf & $38.48 \mathrm{fg}$ & I I I I & $11.00 \mathrm{bd}$ & $33.1 \mathrm{~d}$ & 36.70 ij \\
\hline$M-10$ & 727 cf & $38.33 \mathrm{fg}$ & $81.8 \mathrm{dg}$ & 9.76 ef & 28.6 hj & $28.20 \mathrm{k}$ \\
\hline$M-11$ & $741 \mathrm{bd}$ & $38.56 \mathrm{fg}$ & 80.9 fh & $10.20 \mathrm{df}$ & 29.0 hj & $42.20 \mathrm{gh}$ \\
\hline$M-12$ & 783 a & $40.50 \mathrm{df}$ & 79.4 hı & $10.20 \mathrm{df}$ & $29.2 \mathrm{gl}$ & $42.20 \mathrm{gh}$ \\
\hline$M-13$ & $771 \mathrm{ab}$ & $38.06 \mathrm{gh}$ & I8.6 I I & $10.47 \mathrm{cf}$ & $29.1 \mathrm{gl}$ & $45.70 \mathrm{df}$ \\
\hline$M-14$ & $692 \mathrm{fh}$ & $39.20 \mathrm{eg}$ & $81.3 \mathrm{eg}$ & $11.62 \mathrm{ac}$ & $38.1 \mathrm{ab}$ & $34.45 \mathrm{j}$ \\
\hline S-1 & $771 \mathrm{ab}$ & $43.53 \mathrm{bc}$ & 83.6 ac & $10.37 \mathrm{df}$ & $32.7 \mathrm{de}$ & $34.95 \mathrm{j}$ \\
\hline S-2 & 736 be & $35.93 \mathrm{hl}$ & $83.1 \mathrm{bd}$ & $9.92 \mathrm{df}$ & $29.6 \mathrm{fl}$ & $46.95 \mathrm{ce}$ \\
\hline$S-3$ & 713 cf & 39.70 eg & $82.6 \mathrm{cf}$ & $10.35 \mathrm{df}$ & 28.6 hj & $44.95 \mathrm{eg}$ \\
\hline$S-4$ & 623 jk & $47.33 \mathrm{a}$ & $83.1 \mathrm{bd}$ & $12.55 \mathrm{a}$ & $38.8 \mathrm{a}$ & 39.45 hı \\
\hline$S-5$ & 656 hj & $45.80 \mathrm{ab}$ & I I9.1 & $10.65 \mathrm{bf}$ & $33.1 \mathrm{~d}$ & $57.95 \mathrm{a}$ \\
\hline$S-6$ & 733 be & $39.03 \mathrm{eg}$ & 83.6 ac & $9.55 \mathrm{f}$ & $27.1 \mathrm{j}$ & 39.20 hı \\
\hline S-7 & $750 \mathrm{ad}$ & 44.41 bc & I 79.0 & $10.15 \mathrm{df}$ & زا 27.6 & $34.00 \mathrm{j}$ \\
\hline$S-8$ & $753 \mathrm{ac}$ & $38.31 \mathrm{fg}$ & 78.5 I & 10.80 be & $31.3 \mathrm{df}$ & 39.70 hı \\
\hline S-9 & $746 \mathrm{bd}$ & $38.28 \mathrm{fg}$ & I I8.0 & 10.75 be & $31.1 \mathrm{eg}$ & $35.45 \mathrm{j}$ \\
\hline S-10 & 735 be & $42.38 \mathrm{~cd}$ & $82.3 \mathrm{cg}$ & 10.75 be & 32.4 de & 37.20 i \\
\hline S-11 & $708 \mathrm{df}$ & $40.98 \mathrm{de}$ & $82.3 \mathrm{cg}$ & $11.72 \mathrm{ab}$ & 36.3 bc & $50.20 \mathrm{c}$ \\
\hline GORT & 713 & 39.14 & 81.36 & 10.70 & 31.1 & 41.79 \\
\hline MBG ORT & 707 & 37.35 & 81.30 & 10.70 & 30.7 & 41.75 \\
\hline SBG ORT & 720 & 41.42 & 81.40 & 10.71 & 31.7 & 41.82 \\
\hline
\end{tabular}

TV: Tane verimi; BTA: Bin tane ağırlığl; HL: Hektolitre ağırlı̆̆; PRT: Protein oranı; GLT: Gluten oranı;

ZS: Zeleny sedimantasyon değeri; GORT: Genel ortalama; MBG ORT: Modern buğday genotiplerinin ortalamasl; SBG ORT: Sentetik buğday genotiplerinin ortalaması.

\section{Zeleny Sedimantasyon Değeri}

Zeleny sedimantasyon değeri gluten kalitesini göstergesi olup, protein oranı, bin tane ağırlığı ve tane verimi ile karşıllaştıııldığında farklı çevre veya yılların şartlarından daha az etkilenen, başka bir ifade ile kalıtım derecesi daha yüksek bir karakterdir (Şahin ve ark., 2004). Sedimantasyon değeri bakımından sentetik ve modern ekmeklik buğday genotiplerinin ortalama değeri birbirine yakın, sırasıyla $41.82 \mathrm{ml}$ ve $41.75 \mathrm{ml}$ olarak gerçekleşmiştir. Çalışmada en yüksek sedimantasyon değerine sentetik buğday genotipi S-5 
Aktaş ve ark., Sentetik ve Modern Ekmeklik Buğday Genotiplerinin (Triticum aestivum L.) Verim ve Kalite Özelliklerinin Karşılaştırılması

$(57.95 \mathrm{ml})$ sahip olurken, S-11 genotipi de $50.20 \mathrm{ml}$ ile yüksek sedimantasyon değerine sahip genotip olmuştur. Modern ekmeklik buğday genotipleri içerisinde en yüksek sedimatasyon değerleri $\mathrm{M}-3$ $(56.20 \mathrm{ml}), \quad \mathrm{M}-7 \quad(54.45 \mathrm{ml})$ ve $\mathrm{M}-8(48.95 \mathrm{ml})$ genotiplerinden elde edilmiştir. Pena et al. (2007) Uygun agronomik özelliklere sahip 14 sentetik hexaploid buğday hattı ve melezlemede kullandıkları modern ekmeklik buğday ebeveyninin protein, sedimantasyon ve glutenin alt birimlerini araştırdıkları çalışmada, modern ekmeklik buğdaylardan (Pastör çeşidi gruplarından) üstün olduklarını belirtmiş ve sentetik buğday üretiminde kullanılan yabani türlerin kalite iyileştirme ve kaliteye ait genetik tabanın artırııması için büyük bir potansiyele sahip olduklarını belirtmiştir.

Elde Edilen Verilerin GGE Biplot Yöntemi ile Yorumlanması

Elde edilen verilerin GGE biplot yöntemi ile değerlendirilmesi Şekil 1'de verilmiştir. Biplot analizi sonucunda toplam varyasyon \%66.81 olarak belirlenirken, toplam varyasyonun \%45.83'i PC1 (I. Ana bileşen) ve \%20.97'i ise PC2 (II. Ana bileşen) tarafından temsil edilmiştir. GGE biplot analiz metodolijisine göre poligonun köşelerinde, başka bir ifade ile özelliklerin lokalize olduğu sektörün köşelerinde yer alan genotipler söz konusu özellikler için en yüksek değere veya ideal özelliklere sahip genotipler olarak değerlendirilir (Yan et al., 2000). Buna göre poligonun köşesinde yer alan S-4 başta olmak üzere, S-5, S11 (sentetik buğday genotipleri) ile M-1, M-14 (modern ekmeklik buğday genotipleri) genotipleri protein oranı (PRT), gluten oranı (GLT) ve bin tane ağırlığı karakterleri için en yüksek veya en ideal özelliklere sahip olurken, M3 (3 numaralı modern ekmeklik buğday genotipi) hektolitre $(\mathrm{HL})$ ve zeleny sedimantasyon (ZS) özelikleri için ideal genotip olarak görünmektedir. Tane verimi ise hem modern hem de sentetik buğday genotiplerinin yer aldığı sektörlerin ortasında yer almıştır. Bu durum tane verimi açısından sentetik ve modern ekmeklik buğday genotiplerinin yakın değerlere sahip olduğunu göstermektedir. GGE biplot grafiği incelendiğinde, aynı sektörde birbirine aykın yerde lokalize olan BTA, GLT ve PRT parametreleri arasında; $\mathrm{HL}$ ve $\mathrm{ZS}$ arasında; $\mathrm{ZS}$, PRT ve GLT arasında yüksek bir korelasyon olduğu da anlaşlmaktadır. Benzer sonuçlar bazı araştırıcılar tarafından da bildirilmiştir (Aktaş 2014; Kaya et al., 2014).

Sentetik buğday konusunda birçok rapor sunulmuş olup, bu raporlarda sentetik buğday üretiminde ebeveyn olarak kullanılabilecek yüksek protein, SDS ve sertlik değerine ve daha uzun tane yapısına sahip yabani ve primitiv buğday genotiplerinin (Aeg. squarrosa Tr. dicoccum, Tr. monococcum, Tr. boeoticum gibi) sentetik buğday üretiminde kullanıldığını ve sentetik buğday genotiplerinin bu anlamda üstün özelliklere sahip olduğu bildirilmiştir (Pena et al., 1993; Mujeeb-Kazi et al., 1996). Bir başka raporda tetraploid buğdaylardaki kalite özelliklerinin ekmeklik buğdaylara aktarılabilmesine rağmen elde edilen sentetik buğdaylardaki kalite özelliklerinin mevcut modern ekmeklik buğday genotipleri ile aynı olup olmadığı konusunda soru işaretleri olduğunu ve bu konuda daha kapsamlı çalışmaların yapılması gerektiği belirtilmiştir (Yueming et al., 2003). CIMMYT'de iyi ekmek yapım kalite özelliklerine, aynı zamanda tane tekstürü bakımından potansiyel özgün özelliklere sahip çok sayıda sentetik buğday genotipinin geliştirildiği, buna rağmen bazı buğday ıslahçılarının kendi hedef üretim alanları için sentetik buğday

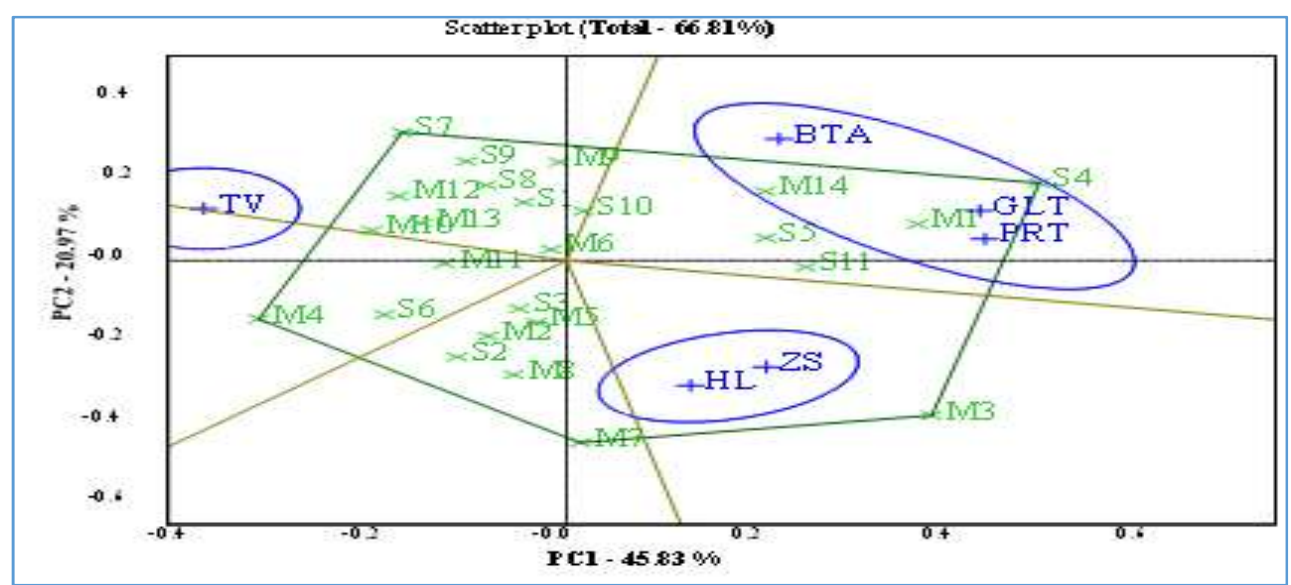

Şekil 1. Genotiplerle incelenen özellikler arasındaki ilişkiyi gösteren GGE biplot grafiği.

Figure 1. GGE biplot scatter plot showing relation between genotypes and examined traits. 
Aktaş ve ark., Sentetik ve Modern Ekmeklik Buğday Genotiplerinin (Triticum aestivum L.) Verim ve Kalite Özelliklerinin Karşılaştırılması

genotiperinin istenilen kaliteye sahip olmadıkları veya kaliteli olsa bile bu üretim çevrelerinde bu genotiplerin damak tadına hitap etmesi konusunda tereddütler olabileceği kaygısıyla sentetik buğdayların ıslahta ebeveyn olarak kullanmaktan çekindikleri rapor edilmiştir (Van - Ginkel and Ogbonnaya 2007).

\section{SONUÇ}

Yapılan bu çalışmada bazı sentetik ve modern ekmeklik buğday çeşitleri tane verimi ve bazı kalite özellikleri açısından karşılaştırılmış, sentetik buğdayların bin tane ağırlığı bakımından bariz bir üstünlüğü belirlenirken, tane verimi bakımından daha yüksek bir ortalama verime sahip olmalarına rağmen bu verim farkının çok az ve bariz bir üstünlük söz konusu olmadığı belirlenmiştir. Protein oranı, sedimantasyon ve yaş gluten oranı bakımından her iki buğday grubu yakın değerlere sahip olmuş, fakat bazı sentetik buğdaylar ise bu özellikler bakımından üstün özelliklere sahip olduğu tespit edilmiştir. Çalışma sonucunda ıslah programlarında dikkatli ve etkili bir seleksiyon ile üstün özelliklere sahip sentetik buğdayların belirlenebileceği ve bu konuda daha kapsamlı çalışmalara ihtiyaç duyulduğu sonucuna varılmıştır.

\section{KAYNAKLAR}

Aguirre A., Badiali O., Cantarero M., Leon A., Ribotta P and Rubido O., 2002. Relationship of test weight and kernel properties to milling and baking quality in argentine triticales. Cereal Research Communications, 30: 1-2.

Aktaş H., 2014. Güneydoğu Anadolu şartlarında bazı ekmeklik buğday çeşitlerinin kalite yönüyle stabilite yetenekleri ve mikro element içeriklerinin araştırılması. Doktora Tezi (Basılmamış), Mustafa Kemal Üniversitesi Fen Bilimleri Enstitüsü, Hatay.

Anonim, 1982. ICC-Standart No:115/1. International Association for Cereal Chemistry, 1982.

Anonim, 1990. AACC Approved Methods of the American Association of Cereal Chemist, USA.

Anonim, 1994. ICC No: 155. International Association for Cereal Chemistry, 1982.

Baloch FS., Karaköy T., Demirbaş A., Toklu F., Özkan H and Hatipoğlu R., 2014. Variation of some seed mineral contents in open pollinated faba bean (Vicia faba L.) landraces from Turkey. Turkish Journal Agriculture and Foresty, 38: 591-602.

Baloch FS., Alsaleh A., Shadid MQ., Çiftçi V., Miera LES., Aasim M., Nadeem MA., Aktaş H., Özkan H and Hatipoğlu R., 2017. A Whole Genome DArT seq and SNP analysis for genetic diversity assessment in durum wheat from Central Fertile Crescent. Plos one, 12(1): 1-18.
Cornish GB., Bekes F., Eagles HA and Payne PI., 2006. Prediction of dough properties for bread wheat. In Gliadin and glutenin: The unique Balance of Wheat (Eds. C Wrigley, F Bekes and W Bushuk), St Paul Minn press, pp. 143-155.

Cox TS., Sears RG., Bequette RK and Martin TJ., 1995. Germplasm enhancement in winter wheat Triticum tauschii backcross populations. Crop Science, 35: 913919.

Dreccer FM., Borgognone GM., Ogbonnaya FC., Trethowan, RM and Winter B., 2007. CIMMYT-selected derived synthetic bread wheats for rainfed environments: yield evaluation in Mexico and Australia. Field Crops Research, 100: 218-228.

Gedye KR., Morris CF., Bettge AD., Freston MJ and King GE., 2004. Synthetic hexaploid wheats can expand the range of purioindoline haplotypes and kernel texture in Triticum aestivum. Proceedings of $54^{\text {th }}$ Australian Cereal Chemistry Conference and $11^{\text {th }}$ Wheat Breeders Assembly, 21 -24 Semtemper, Australia.

Hajjar R and Hodgkin T., 2007. The use of wild relatives in crop improvement: A survey of developments over the last 20 years. Euphytica, 156: 1-13.

Kaya Y and Akçura M., 2014. Effects of genotype and environment on grain yield and quality traits in bread wheat ( $T$. aestivum L.). Food Science Technology Campinas, 34(2): 386-393.

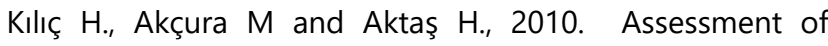
parametric and non-parametric methods for selecting stable and adapted durum wheat genotypes in multienvironments. Notulae Botanicae Horti Agrobotanici Cluj-Napoca, 38: 271-279.

Lage J., Skovmand B., Peña RJ and Andersen SB., 2006. Grain quality of Emmer wheat derived synthetic hexaploid wheats. Genetic Resources and Crop Evolution, 53: 955962.

Lage J and Trethowan RM., 2008. CIMMYT's use of synthetic hexaploid wheat in breeding for adaptation to rainfed environments globally. Australian Journal of Agriculture Research, 59: 461-469.

Luo M., Yang $Z$ and Zhang $H_{\text {., }}$ 1998. The structure of the Aegilops tauschii genepool and the evolution of hexaploid wheat. Theoretical and Applied Genetics, 97: 657-670.

Mujeeb-Kazi A., Rosas V and Roldan S., 1996. Conservation of the genetic variation of Triticum tauschii (Coss.) Schmal. (Aegilops squarrosa auct. non L.) in synthetic hexaploid wheats ( $T$. turgidum L. s.lat. $\cdot T$. tauschii; $2 n=$ $6 x=42, A A B B D D)$ and its potential utilization for wheat improvement. Genetic Resources and Crop Evolation, 43: 129-134.

Ogbonnaya FC., Ye G., Trethowan R., Dreccer F., Sheppard J and Van Ginkel M., 2006. Yield of synthetic backcross- 
Aktaş ve ark., Sentetik ve Modern Ekmeklik Buğday Genotiplerinin (Triticum aestivum L.) Verim ve Kalite Özelliklerinin Karşılaştırılması

derived lines in rainfed environments of Australia. Euphytica, 157: 321- 332.

Pask AJD., Pietragalla J., Mullan DM and Reynolds MP., 2012. Physiological Breeding II: A Field Guide to Wheat Phenotyping. Mexico City, Mexico: CIMMY.

Pena RJ., Skovmand B and Amaya A., 1993. Glutenin (HMW and (MW-) Subunit Composition, Quality Characteristics and Their Relationship in Triticum dicoccon Populations. $8^{\text {th }}$ International Wheat Genetics Symposium, 20-25 July, Beijing, China.

Pena RJ., Cervantes- Espinosa Ml., Posads G., Ortizmonasterio Jl and Dubat A., 2007. Gluten composition, gluten quality, and dought properies (National Mixograph; Chopin -Mixolab) of high yielding wheats derived from crosses between common (T. aestivum) and synthetic ( Triticum dicoccum $x$ Aeligops Taushii) wheats. Journal of Cereal Science, 78: 243-249.

Rahman MM., Hossain A., Hakim MA and Kabir MR and Shah MMR., 2009. Performance of wheat genotypes under optimum and late sowing condition. International Journal of Sustain Crop Production, 4(6): 34-39.
Şahin M., Göçmen A ve Aydoğan S., 2004. Ekmeklik buğdayda Mini SDS (Sodyum Dodesil Sülfat) sedimantasyon testi ile bazı kalite özellikleri arasındaki ilişkilerin belirlenmesi. Bitkisel Araştırma Dergisi, 2: 1-5.

Valkoun JJ., 2001. Wheat pre-breeding using wild progenitors. Euphytica, 119: 17-23.

Van-Ginkel M and Ogbonnaya F., 2007. Novel genetic diversity from synthetic wheats in breeding cultivars for changing production conditions. Field Crop Research, 104: 86-94.

Yan W Hunt LA., Sheng Q and Szlavnics Z., 2000. Cultivar evaluation and mega environment investigation based on the GGE biplot. Crop Science, 40: 597-605.

Yueming Y., Hsam SLK., Jianzhong Y., Jiang $Y$ and Zeller F.J., 2003. Allelic variation of the HMW glutenin subunits in Aegilops tauschii accessions detected by sodium dodecyl sulphate (SDS-PAGE), acid polyacrylamide gel (A-PAGE) and capillary electrophoresis. Euphytica, 130: 377-385. 